Premiere Educandum: Jurnal Pendidikan Dasar dan Pembelajaran

Volume 8(2) 196 - 205 Desember 2018

Copyright $(2018$ Universitas PGRI Madiun

ISSN: 2088-5350 (Print) / ISSN: 2528-5173 (Online)

Available at: http://e-journal.unipma.ac.id/index.php/PE

Doi: $10.25273 /$ pe.v8i2.3021

\title{
Pengaruh model pembelajaran student team achievement devision (STAD) dan mind mapping terhadap hasil belajar siswa kelas IV sekolah dasar
}

\author{
Fakhriyatu Zahro' $^{1)}$, I Nyoman Sudana Degeng ${ }^{2)}$ \& Alif Mudiono ${ }^{3)}$ \\ ${ }^{123)}$ Pendidikan Dasar, Pascasarjana, Universitas Negeri Malang \\ 1)email: fakhriyatu@gmail.com \\ ${ }^{2)}$ email: nyoman.sudana.d.fip@um.ac.id \\ ${ }^{3)}$ email: alifmudiono@gmail.com
}

\begin{abstract}
This study aims to determine the effect of STAD learning models and Mind Mapping on learning outcomes of fourth grade elementary school students. The research method used is quasi experiment with non equivalent control group design. Research data collected by using the instrument learning outcome test in the form of multiple choice questions. The results shows that, (1) the average value of student learning outcomes that apply STAD and Mind Mapping learning models is superior to the average value of students who apply conventional learning models, (2) there is a significant influence of STAD learning models and Mind Mapping towards student learning outcomes
\end{abstract}

Keywords: STAD learning model, Mind Mapping, Learning Outcome, Elementary School Student.

Abstrak
Penelitian ini bertujuan untuk mengetahui pengaruh model pembelajaran STAD dan Mind Mapping terhadap hasil belajar siswa kelas IV SD. Metode penelitian yang digunakan yaitu quasi experiment dengan rancangan non equivalent control group. Data penelitian yang dikumpulkan dengan menggunakan instrumen tes hasil belajar berupa soal pilihan ganda. Hasil penelitian menunjukkan bahwa, (1) rata-rata nilai hasil belajar siswa yang menerapkan model pembelajaran STAD dan Mind Mapping lebih unggul dibandingkan rata-rata nilai siswa yang menerapkan model pembelajaran konvensional, (2) ada pengaruh yang signifikan model pembelajaran STAD dan Mind Mapping terhadap hasil belajar siswa.

Kata Kunci: Model pembelajaran STAD, Mind Mapping, Hasil Belajar, Siswa Sekolah Dasar.

Histori artikel : disubmit pada 25 Agustus 2018; direvisi pada 13 September 2018; diterima pada 09

Desember 2018

\section{A. PENDAHULUAN}

Pembelajaran merupakan suatu proses untuk membelajarkan seseorang tentang suatu informasi atau konsep melalui pengalaman. Slavin (2015) menyatakan bahwa pembelajaran merupakan proses perubahan tingkah laku seseorang melalui pengalaman. Perubahan tingkah laku yang dimaksud yaitu mencakup ranah kognitif, afektif, dan psikomotorik. Seorang anak SD mengikuti proses pembelajaran merupakan suatu hal yang sulit serta 
perlu mendapat bimbingan yang efektif dari pengajar atau guru..

Kurikulum 2013 seluruhnya menggunakan pembelajaran tematik terpadu. Majid (2014) mengemukakan bahwa pembelajaran tematik adalah pendekatan pembelajaran yang mengaitkan beberapa mata pelajaran ke dalam sebuah tema. Dengan pembelajaran yang dilakukan secara terpadu tersebut, peserta didik akan mengalami pembelajaran yang bermakna sehingga tercapai kompetensi baik pengetahuan, sikap, maupun keterampilan. Pembelajaran tematik ini berfungsi untuk mempermudah siswa dalam memahami dan mendalami konsep materi yang tergabung dalam tema dan terbagi menjadi beberapa subtema. Setiap subtema terdiri dari enam pembelajaran.

Pembelajaran tematik terpadu dalam Kurikulum 2013 menggunakan pendekatan saintifik (saintific approach). Dalam pendekatan saintifik, guru menyajikan permasalahan yang sering terjadi di dalam kehidupan peserta didik, kemudian peserta didik diminta untuk mencoba mencari jawaban atas permasalahan tersebut. Dengan demikian pendekatan saintifik dapat melatih siswa untuk berpikir secara kritis terhadap masalah-masalah di lingkungannya. Keterampilanketerampilan dalam pendekatan saintifik meliputi keterampilan 5M yang terdiri dari mengamati (observing), menanya (questioning), mencoba (experimenting), menalar (associating) dan mengkomunikasikan (communicating) (Hosnan, 2014).
Pembelajaran tematik terpadu dengan menggunakan pendekatan saintifik disarankan menggunakan model pembelajaran berbasis pendekatan konstruktivisme. Abimanyu (2008) mengemukakan bahwa konstruktivisme adalah suatu pendekatan pembelajaran yang meyakini bahwa peserta didik membangun pengetahuan berdasarkan pengalaman mereka sendiri. Sependapat dengan hal itu, Sardiman (2014) juga mengemukakan bahwa pengetahuan siswa merupakan hasil dari konstruksi siswa itu sendiri yang mengetahui sesuatu.

Model pembelajaran yang berbasis pendekatan konstruktivisme banyak dikembangkan oleh para ahli. Dalam hal ini Baharudin \& Wahyuni (2015) menuliskan model-model pembelajaran yang menggunakan pendekatan konstruktivisme antara lain: discovery learning, reception learning, cooperative learning, assisted learning, active learning, the accelerated learning, quantum learning, dan contextual teaching and learning (CTL). Dengan menggunakan model - model pembelajaran tersebut maka aktivitas siswa akan meningkat.

Saat ini proses pembelajaran yang dilaksanakan seharusnya dapat membuat siswa untuk saling bekerja sama dengan siswa lain. Rusmawati (2013) mengatakan bahwa pembelajaran yang dilaksanakan dapat mengadaptasi dari kehidupan seharihari, dimana manusia dalam menjalani kehidupannya memerlukan bantuan orang lain sehingga tidak dapat hidup sendiri. Jika hal ini diterapkan dalam proses pembelajaran, maka akan 
muncul pembelajaran kooperatif dimana siswa diminta untuk dapat bekerja dalam kelompok-kelompok kecil dalam penguasaan materi. Penerapan model pembelajaran kooperatif diharapkan siswa dapat bertindak lebih aktif dalam proses pembelajaran. Pembelajaran kooperatif adalah penggunaan pembelajaran dengan kelompok kecil sehingga siswa dapat bekerja sama untuk memaksimalkan pembelajarannya sendiri dan orang lain (Kagan \& Kagan, 2009). Semua pelajaran dapat dilakukan secara bekerja sama untuk semua usia siswa.

Ada lima model pembelajaran kooperatif menurut Slavin (2015) yaitu: STAD (Students Teams Achievment Divisions), Jigsaw II, TAI (Team Assisted Individualization) TGT (Teams Games Tournament), CIRC (Cooperative Integrated Reading and Composition). Peneliti memilih menggunakan model pembelajaran STAD. Menurut Slavin (2015) STAD merupakan model pembelajaran kooperatif yang paling baik untuk permulaan bagi guru yang baru menggunakan pendekataan kooperatif.

STAD merupakan salah satu model pembelajaran kooperatif yang dirasa efektif pada suatu pembelajaran. STAD menekankan pada interaksi dan juga aktivitas siswa agar bisa saling mendukung dalam penguasaan pelajaran yang berdampak pada hasil belajar. Menurut Slavin (2015) pembelajaran STAD mengajari siswa untuk bekerja sama pada suatu tugas bersama dan mereka harus mengkoordinasi usaha secara bersama untuk menyelesaikannya. Degeng, dkk. (2016) menyatakan bahwa pada proses pembelajaran kooperatif, pemberian tugas pada siswa dirancang guna mendorong semua anggota kelompok untuk aktif dalam belajar melalui usaha mereka sendiri dan usaha anggota kelompok bertujuan demi keberhasilan kelompok mereka sendiri. Meski para siswa belajar bersama, mereka tidak boleh saling membantu dalam mengerjakan kuis. Tiap siswa harus tahu materinya. Tanggung jawab individual seperti ini memotivasi siswa untuk memberi penjelasan dengan baik satu sama lain, karena satu-satunya cara tim untuk berhasil adalah dengan membuat semua anggota menguasai materi.

Model pembelajaran STAD diharapkan mampu meningkatkan hasil belajar kognitif siswa. Hal ini didasarkan pada beberapa hasil penelitian terdahulu yang telah dilakukan. Dalam penelitian Alfiani (2014) menunjukkan temuan bahwa model pembelajaran STAD berpengaruh secara signifikan terhadap hasil belajar siswa kelas V Di SD Negeri 1 Tersana Kecamatan Pabedilan Kabupaten Cirebon. Terdapat perbedaan yang signifikan hasil belajar IPA siswa antara kelas eksperimen dengan kelas kontrol.

Penelitian Tatalia (2016) menyimpulkan bahwa model pembelajaran kooperatif tipe STAD mempengaruhi kemampuan menulis teks berita siswa. Pengaruh tersebut dapat dijelaskan sebagai berikut. Pertama, kemampuan menulis teks berita siswa yang diajar dengan model pembelajaran kooperatif tipe STAD lebih baik daripada kemampuan menulis teks berita siswa yang diajar 
dengan model pembelajaran konvensional. Kedua, kemampuan menulis teks berita siswa bermotivasi belajar tinggi yang diajar dengan model pembelajaran kooperatif tipe STAD lebih baik daripada kemampuan menulis teks berita siswa bermotivasi belajar tinggi yang diajar dengan model pembelajaran konvensional. Ketiga, terdapat pengaruh kemampuan menulis teks berita siswa yang diajar dengan model pembelajaran kooperatif tipe STAD dengan model pembelajaran konvensional menunjukkan substansi pembelajaran yang lebih tinggi perbandingannya, dibandingkan kelas yang menggunakan pembelajaran tradisional.

Selanjutnya penelitian Tarim \& Math (2008) tentang Pengaruh pembelajaran kooperatif terhadap prestasi dan sikap matematika siswa SD Turki terhadap matematika menggunakan metode TAI dan STAD.

Sebagai hasil Penelitian tersebut terbukti bahwa metode STAD dan TAI ternyata memiliki efek positif (d $=1,003$ untuk STAD dan $\mathrm{d}=0,40$ untuk TAI) terhadap prestasi akademik siswa dalam matematika. Perbandingan berpasangan menunjukkan bahwa metode STAD memiliki efek yang lebih signifikan daripada metode TAI.

Hasil penelitian terdahulu yang dilakukan oleh Agustini \& Hartono (2015) tentang "Pengaruh Student Teams Achievement Division (STAD) Terhadap Hasil Belajar Matematika Di SDLB-B Karya Mulia I Surabaya". Berdasarkan pengolahan data dengan menggunakan teknik analisis hasil belajar matematika siswa kelas III
SDLB-B Karya Mulia I Surabaya dengan menggunakan metode Student Teams Achievement Divisin (STAD) menunjukan peningkatan hasil belajar. Dalam penerapan Student Teams Achievement Division pada siswa kelas III SDLB-B Karya Mulia I Surabaya dapat memberikan suasana yang baru dan segar daripada pembelajaran seperti biasa. Siswa menjadi lebih aktif didalam kelas dan lebih termotivasi untuk mendapatkan nilai yang lebih baik.

Model pembelajaran STAD juga memiliki beberapa kekurangan. Menurut Slavin (2015) kelemahan dari model STAD adalah kontribusi dari siswa berkemampuan rendah berkurang dan siswa yang berkemampuan tinggi akan mengarah pada kekecewaan, hal ini disebabkan oleh peran anggota kelompok yang pandai yang lebih dominan. Jika mengikuti cara berpikir siswa yang pandai, maka sulit diikuti oleh siswa berkemampuan rendah. Demikian pula sebaliknya, jika mengikuti cara berpikir siswa yang berkemampuan rendah maka siswa yang pandai menjadi bosan dan jenuh dan ingin segera berganti dengan materi selanjutnya

Untuk mencapai standar kemampuan yang seharusnya dikuasai oleh siswa maka peneliti menggabungkan metode mind mapping. Mind mapping adalah alat pikir organisasional yang sangat hebat sehingga memudahkan untuk menempatkan informasi ke dalam otak dan mengambil informasi di luar dari otak. Penelitian oleh D'Antoni \& Zipp (2005) menemukan bahwa dari kumpulan 14 siswa physical therapy, 
10 dari 14 siswa sepakat bahwa teknik mind mapping memungkinkan mereka untuk lebih mengatur dan mengintegrasikan materi yang disampaikan.

Mind mapping merupakan cara mencatat kreatif, efektif, dan secara harfiah akan memetakan pikiranpikiran (Buzan, 2013:40). Mind mapping sebagai alat bantu yang dibuat siswa untuk mengungkapkan pemikiran mereka. Siswa diminta untuk membuat mind mapping dari penjelasan yang diberikan oleh guru. Dalam hal ini, guru memberi kebebasan berpikir kepada siswa dan siswa bebas menentukan cara penyelesaian yang logis dan rasional. Kemudian siswa mempresentasikan hasil pemikiran mereka. Sebuah studi yang diterapkan oleh Toi (2009) menunjukkan bahwa mind mapping dapat membantu anak-anak mengingat kata-kata lebih efektif dari pada menggunakan daftar, dengan peningkatan dalam ingatan hingga $32 \%$. Hal ini akan membuat siswa meningkatkan rasa percaya diri. Setelah itu dievaluasi dan diberi penghargaan.

Pertimbangan lain menggunakan bantuan mind mapping, yaitu melatih otak melihat secara menyeluruh sekaligus secara terperinci dan dalam hal ini terjadi integrasi antara logika dan daya khayal. Mind mapping juga membantu memberi pandangan menyeluruh pokok masalah, memungkinkan siswa merencanakan atau membuat pilihan, mengumpulkan sejumlah besar data di satu tempat, mendorong kemampuan pemecahan masalah, dan menyenangkan untuk dilihat, dibaca, dicerna dan diingat
(Buzan, 2013). Selain itu, mind mapping membantu siswa untuk menyerap informasi baru, untuk berpikir dan mengembangkan skema konseptual (Keles, 2012).

Penelitian Riyanto (2013) dengan judul "Pengaruh Metode Mind Mapping Terhadap Ketuntasan Belajar IPA pada Siswa Full Day School" memberikan kesimpulan bahwa metode "Mind Mapping" yang diaplikasikan dalam pembelajaran berpengaruh pada ketuntasan belajar IPA pada siswa Full Day School. Penelitian Ikhwanuddin (2013) dengan judul "Penerapan Metode Mind Mapping untuk Meningkatkan Keterampilan Menulis Karangan Narasi pada Siswa Kelas IVA SDN Wonosari 02 Semarang" memberikan kesimpulan bahwa Keterampilan menulis siswa mengalami peningkatan, nilai rata-rata pada siklus I sebesar 63,38 meningkat menjadi 70,95 pada siklus II. Dengan persentase ketuntasan sebesar $75,67 \%$ pada siklus I meningkat menjadi 89,19\% pada siklus II. Mengacu pada indikator keberhasilan penelitian yang menetapkan sebesar $75 \%$ siswa mengalami ketuntasan dalam menulis, maka penelitian ini dinyatakan berhasil.

Berdasarkan kajian teori dan hasil peneltian sebelumnya, peneliti tertarik untuk melakukan penelitian dengan fokus utamanya adalah menggabungkan metode mind mapping dengan model pembelajaran STAD untuk mengetahui pengaruhnya terhadap hasil belajar siswa Kelas IV Sekolah Dasar. 


\section{B. METODE PENELITIAN}

Metode penelitian yang digunakan yakni penelitian Quasi Experiment, adapun rancangan penelitian yang digunakan yaitu Non Equivalent Control Group. Populasi penelitian adalah siswa kelas IV A dan IV B di SD Negeri Sawojajar 01 Kota Malang tahun pelajaran 2018/2019 dengan jumlah keseluruhan sebanyak 84 siswa. Adapun kelas IV A sebagai kelas kontrol yang menerapkan model pembelajaran konvensional (ceramah, diskusi) dan kelas IV B sebagai kelas eksperimen yang menerapkan model pembelajaran STAD dan Mind Mapping.

Variabel penelitian ini yaitu, (1) model pembelajaran STAD dan Mind Mapping sebagai variabel independent (bebas), (2) hasil belajar siswa kelas IV sebagai dependent (terikat). Instrument yang digunakan untuk mengumpulkan data yaitu tes hasil belajar berupa soal pilihan ganda yang sebelumnya sudah di validasi konstruk pada dosen dan guru, selain itu juga telah divalidasi empirik pada siswa lain sehingga butir soal sudah dapat dikatakan valid dan reliabel.

Penelitian ini menggunakan metode analisis deskriptif statistik parametrik. Uji hipotesis dilakukan dengan Uji Independent T-test (uji T) dengan bantuan SPSS 20.0 for Windows. Sebelum melakukan analisis data dan uji hipotesis, data yang diperoleh perlu diuji asumsinya terlebih dahulu yang dilakukan dengan uji normalitas dan homogenitas varians. Uji normalitas dilakukan dengan uji Kolmogorov Smirnov sedangkan uji homogenitas dilakukan dengan uji Levene's Test.

\section{HASIL DAN PEMBAHASAN}

Gain score merupakan hasil progress yang diperoleh dengan melakukan pengurangan nilai posttest dengan pretest. Hasil selisih nilai hasil belajar tersebut digunakan untuk mengetahui peningkatan dari proses pembeljaran yang dilaksanakan pada kedua kelas, yakni kelas eksperimen yang menerapkan model STAD berbantuan Mindmap dan kelas kontrol yang menerapkan model konvensional (ceramah-diskusi kelompok). Gain score pada kedua kelas dapat dilihat pada Gambar 1.

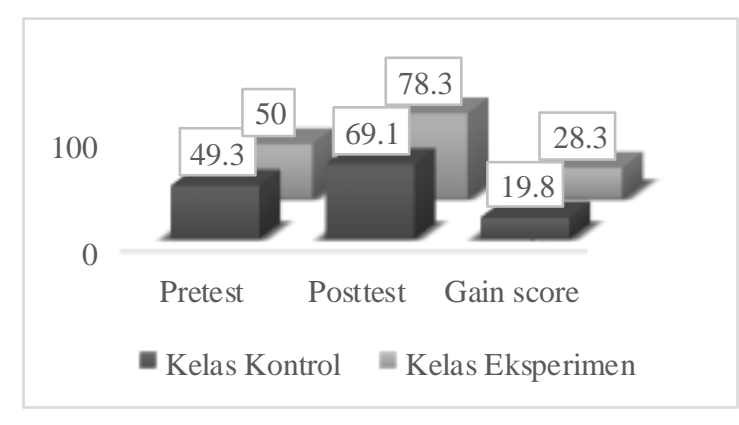

\section{Gambar 1 Gain Score Kedua Kelas}

Berdasarkan Gambar 1 di atas menunjukkan pada kelas kontrol ratarata nilai hasil belajar pretest diperoleh sebesar 49,3 sedangkan kelas eksperimen memperoleh nilai rata-rata sebesar 50. Rata-rata nilai hasil belajar posttest pada kelas kontrol sebesar 69,1 sedangkan pada kelas eksperimen rata-rata nilai hasil belajar sebesar 78,3. Adapun gain score pada kelas kontrol sebesar 19,8 sedangkan gain score pada kelas eksperimen sebesar 28,3. Dari data di atas dapat disimpulkan bahwa gain score hasil belajar pada kelas eksperimen yang menerapkan model pembelajaran STAD dan Mind Mapping lebih unggul dibandingkan dengan gain score hasil belajar kelas kontrol yang 
menerapkan model pembelajaran konvensional (ceramah-diskusi). Hal tersebut menunjukkan bahwa model pembelajaran STAD dan Mind Mapping mampu memberikan pengaruh yang lebih besar terhadap hasil belajar siswa

Berdasarkan hasil uji $t$, dapat dilihat bahwa hasil perhitunan uji-t diperoleh nilai t-hitung sebesar -2.810 dengan nilai Signifikansi Sig. (2tailed) 0,006 atau kurang dari 0,05 $(0,006<0,05)$ sehingga hipotesis nol ditolak dan hipotesis penelitian diterima. Dengan demikian, dapat disimpulkan bahwa ada pengaruh model pembelajaran STAD dan Mind Mapping terhadap hasil belajar siswa kelas IV SD.

Secara umum temuan penelitian ini mendeskripsikan apa yang diharapkan bahwa secara teoritis model pembelajaran STAD dan Mind Mapping berpengaruh terhadap hasil belajar siswa kelas IV Sekolah Dasar. Hal ini dapat ditunjukkan dengan hasil perhitungan uji Independent T-test pada hasil belajar siswa pada kedua kelas baik kelas ekperimen yang menerapkan model STAD dan Mind Mapping dengan kelas kontrol yang menerapkan model konvensional (ceramah-diskusi kelompok). Melalui uji Independent T-test hasil belajar siswa pada kelas kontrol dan kelas ekperimen menunjukkan perbedaan hasil belajar ditandai dengan harga value $p$-value $<0,05$, dengan kata lain hipotesis nol ditolak.hal tersebut menunjukkan bahwa ada pengaruh positif model pembelajaran STAD dan Mind Mapping terhadap hasil belajar siswa kelas IV Sekolah Dasar.

\section{Hasil Belajar Siswa yang Menerapkan Model Pembelajaran STAD dan Mind Mapping}

Hasil belajar siswa sebelum diberikan perlakuan menunjukkan tidak ada perbedaan yang signifikan. Hal tersebut dapat dilihat dari hasil pretest yang dilakukan dengan perolehan rata-rata nilai pada kelas kontrol sebesar 49,3 dan rata-rata 50 pada kelas eksperimen. Namun setelah diberikan perlakuan pada kedua kelas dan kemudian dilakukan posttest pada kelas kontrol yang menerapkan model konvensional (ceramah-diskusi kelompok) memperoleh rata-rata hasil belajar sebesar 69,1 sedangkan pada kelas eksperimen yang menerapkan model STAD dan Mind Mapping memperoleh rata-rata hasil belajar sebesar 78,3. Hal tersebut menunjukkan bahwa hasil belajar siswa yang menerapkan model pembelajaran STAD dan Mind Mapping mengalami peningkatan yang signifikan.

Sejalan dengan Degeng (2005), menjelaskan bahwa segala efek yang di peroleh dapat dijadikan sebagai indikator tentang nilai dari penggunaan suatu metode pembelajaran dibawah kondisi yang berbeda. Oleh karena itu hasil penelitian yang dilakukan menunjukkan bahwa model pembelajaran STAD dan Mind Mapping disini memberikan peningkatan yang positif terhadap hasil belajar siswa. Hal ini didukung oleh hasil penelitian Hadinata (2017) menunjukkan bahwa model STAD dan diskusi dapat meningkatkan hasil belajar siswa kelas IV. Hasil penelitian Tatalia (2017) menunjukkan hasil 
belajar kemampuan menulis teks berita pada siswa yang diajar menggunakan model pembelajaran STAD lebih baik dibandingkan dengan hasil belajar kemampuan menulis pada siswa yang diajar menggunakan model pembelajaran konvensional.

Adanya peningkatan hasil belajar siswa yang baik tidak terlepas dari penguasaan konsep dari materi yang sedang dipelajari oleh siswa. Hal tersebut sejalan dengan Brinkman (2003) bahwa Mind Mapping dapat membantu siswa dalam mendukung proses berpikir alami siswa, sehingga dapat menghasilkan dan mengintegrasikan dengan hubungan ide-ide menjasi suatu pemahaman konsep pada siswa. Sejalan dengan penelitian dari Hidayat (2017) menjelaskan bahwa metode pembelajaran yang dibantu dengan mind mapping sangat tepat digunakan untuk meningkatkan hasil belajar siswa. Hasil penelitian oleh Arfiyanti (2017) menunjukkan bahwa mind mapping juga mampu mengembangkan hal lain yang lebih khusus seperti pemahaman konsep himpunan pada siswa.

\section{Pengaruh Model Pembelajaran STAD dan Mind Mapping terhadap Hasil Belajar}

Berdasarkan hasil analisis data tentang pengaruh model pembelajaran STAD dan Mind Mapping terhadap hasil belajar siswa dapat diketahui bahwa terdapat pengaruh yang signifikan dari penerapan model pembelajaran STAD dan Mind Mapping terhadap hasil belajar siswa. Pengaruh ditunjukkan dari hasil analisis melalui uji Independent T-test dengan nilai Signifikansi 0,006 atau kurang dari $0,05 \quad(0,006<0,05)$ sehingga hipotesis nol ditolak dan hipotesis penelitian diterima. Dapat disimpulkan bajwa ada pengaruh penerapan model pembelajaran STAD dan Mind Mapping terhadap hasil belajar siswa.

Berdasarkan hasil analisis deskriptif statistik dari perolehan ratarata hasil belajar siswa yang menerapkan model pembelajaran STAD dan Mind Mapping lebih tinggi dibandingkan dengan siswa yang menerapkan model pembelajaran konvensional (ceramah - diskusi kelompok). Nilai rata-rata hasil belajar siswa yang menerapkan model pembelajaran STAD dan Mind Mapping sebesar 78,3, sedangakan nilai rata-rata hasil belajar yang menerpakan model pembelajaran konvensional (ceramah-diskusi kelompok) hanya sebesar 69,1. Hal ini menunjukkan bahwa penerapan model pembelajaran STAD dan Mind Mapping lebih efektif dibandingkan dengan model pembelajaran konvensional (ceramah-diskusi kelompok) dalam meningkatkan hasil belajar siswa.

Pernyataan tersebut sejalan dengan penelitian yang dilakukan oleh Adrian (2016) membuktikan bahwa ada pengaruh model pembelajaran STAD terhadap hasil belajar yang terlihat dari nilai gain score hasil belajar siswa kelas eksperimen lebih tinggi dibandingkan dengan gain score hasil belajar siswa kelas kontrol. Hasil penelitian oleh Fauzi (2017) menyimpulkan bahwa model pembelajaran STAD variasi kartu panggilan memberikan pengaruh yang 
signifikan terhadap hasil belajar siswa kelas IV SDN Kuin Utara 4 Banjarmasin. Penerapan model pembelajaran STAD pada penelitian terdahulu memang sudah memberikan adanya pengaruh yang positif terutama pada hasil belajar siswa, namun tidak kalah penting dalam penelitian ini adanya peran Mind Mapping dalam membantu siswa dalam penguasaan materi pelajaran. Hal tersebut sejalan dengan penelitian yang dilakukan oleh Sayekti (2017) menunjukkan bahwa penerapan mind mapping dalam pembelajaran dapat meningkatkan pemahaman materi sehingga dapat memberikan pengaruh terhadap hasil belajar siswa. Hasil penelitian oleh Leliavia (2017) juga menunjukkan adanya pengaruh penerapan mind mapping terhadap hasil belajar siswa dibandingkan dengan siswa yang tidak diberikan tugas untuk membuat mind mapping.

\section{SIMPULAN}

Berdasarkan hasil penelitian yang diperoleh dan dibahas pada bab sebelumnya, beberapa hal yang dapat disimpulkan dalam penelitian ini, yaitu: (1) hasil belajar rata-rata siswa pada kelas yang menerapkan model pembelajaran konvensional (ceramahdiskusi kelompok) sebesar 69,1 dan hasil rata-rata siswa pada kelas yang menerapkan model pembelajaran STAD dan Mind Mapping sebesar 78,3. Hal ini membuktikan bahwa hasil belajar siswa pada kelas eksperimen yang menerapkan model pembelajaran STAD dan Mind Mapping lebih tinggi dibandingkan dengan kelas control, dan (2) ada pengaruh model pembalajaran STAD dan Mind Mapping terhadap hasil belajar siswa kelas IV Sekolah Dasar.

Berdasarkan hasil penelitian ini, dapat disampaikan saran untuk berbagai pihak berhubungan dengan hasil penelitian ini, yaitu (1) bagi guru, hasil penelitian ini menunjukkan bahwa model pembelajaran STAD dan Mind Mapping memberikan pengaruh terhadap hasil belajar siswa, namun ada beberapa hal yang perlu diperhatian bahwa, (a) guru harus menguasai model pembelajaran STAD, (b) melakukan pembiasaan menerapkan mind mapping dalam kelas, sehingga siswa akan terbiasa mengikuti tahap-tahap pada mode pembelajaran ini, (c) berikan intruksi yang jelas dalam setiap langkah penerapan model pembelajaran ini, (2) bagi kepala sekolah, hendaknya mendukung dan memberikan dorongan berupa motivasi, serta mensosialisasikan penerapan model pembelajaran STAD dan Mind Mapping kepada para guru agar hasil belajar siswa meningkat, dan (3) bagi peneliti lanjutan, dalam peningkatan hasil belajar siswa dengan menerapkan model pembelajaran STAD dan Mind Mapping faktor pendukung lain juga perlu diperhatikan. Peneliti merasa aktivitas dan kreativitas siswa juga dapat mempengaruhi hasi belajar siswa. Oleh karena itu untuk peneliti lanjut diharapkan melakukan penelitian untuk mengetahui pengaruh model pembelajaran STAD dan Mind Mapping terhadap aktivitas ataupun kreativitas siswa.

\section{DAFTAR RUJUKAN}

Arfiyanti, D., Irawan, E.B., \& Purwanto. (2017) . Peningkatan 
Pemahaman Konsep Himpunan Melalui Mind Mapping Kelas VII SMP. Jurnal Pendidikan: Teori, Penelitian, dan Pengembangan. 2 (6): 799-805.

Buzan, T. (2014). Part 2: The Evidence Supporting Mind Mapping. Mind Mapping: Scientific Research and studies. (Ebook online), (http://pdfmanual.niamz.net/pdf/ mind-mapping-scientificresearchand.html, diakses 5 November 2017.

Degeng, I Nyoman S.(2005). Belajar dan Pembelajaran. Malang: Laboratorium Teknologi Pendidikan FIP UM.

Fauzi, Z. A. (2017). Pengaruh Pembelajaran Kontekstual Berbasis Mind Mapping terhadap Hasil Belajar Siswa Kelas IV di SDN Mawar 2 Banjarmasin. Tesis. Tidak diterbitkan: Pascasarjana Universitas Negeri Malang.

Hadinata, L. Q., Utaya, S., \& Setyosari P. (2017) Pengaruh Pembelajaran Studen Team Achievemnt division dan diskusi terhadap hasil belajar IPA Kelas IV SD. Jurnal Pendidikan: teori, penelitian dan pengembangan. 2(7): 979-985.
Hidayat, I., Towaf S. M., Ruminiati. (2017). Penerapan model pembelajaran cooperative script berbantuan mind map untuk meningkatkan keterampilan berpikir kritis dan hsil belajar IPS siswa kelas V. Jurnal Pendidikan: teori, penelitian dan pengembangan. 2(4): 562-568.

Hosnan. (2014). Pendekatan Saintifik dan Kontekstual dalam Pembelajaran Abad 21: Kunci Sukses Implementasi Kurikulum 2013. Bogor: Ghalia Indonesia.

Kagan, S. \& Kagan, M. (2009). Kagan Cooperative Learning. Terjemahan Budi Eko Soetjipto. San Clemente: Kagan Publishing

Majid, A. (2014). Penilaian Autentik Proses dan Hasil Belajar. Bandung: PT Remaja Rosdakarya.

Sayekti, E., Suwono, H., Sueb. (2017). Pengaruh Model Pembelajaran Inkuiri Sains berbantuan Mind Mapping terhadap hasil belajar biologi siswa kelas X SMA. Jurnal Pendidikan: teori, penelitian, dan pengembangan. 2 (4): 550-555.

Slavin, R. E. (2015). Cooperative Learning Teori, Riset, dan Praktik. Bandung: Nusa Media. 